\title{
Changes In The Development Process Of Mobile Phone Applications Bring Opportunities For Developers And More Options To Consumers
}

\author{
Kristen M. Maceli, Pittsburg State University, USA
}

\begin{abstract}
Consumers are becoming increasingly comfortable with technology. As their knowledge and use of technology has increased, so too have their expectations and roles in the technology environment. New technology brings about new products, and the process of developing new products is ongoing. Research and development, turnaround times, product introduction timing, and development efforts of the competition all influence the process. The race to move new technology to the market as quickly as possible has significantly changed the development process. Individuals now have development opportunities that generally belonged to corporations years ago. As Smartphones become more mainstream, the race to create applications (apps) for the devices has presented entrepreneurial opportunities for companies and individuals alike. Not only is the demand for apps increasing, but the power of apps is also increasing. Apps have the ability to affect consumer demands and, ultimately, impact what is available in the marketplace.
\end{abstract}

Keywords: apps; Internet; Android system; Apple system

\section{INTRODUCTION}

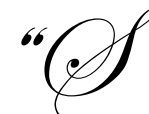

ince the development of the Internet, we have witnessed technological advancements at lightning speed, unparalleled to any in our history. And, we are now unable to keep up with these new apps, phones, softwares, etc. Computers are taking over when we cannot quickly digest the newness...As of June 30,2010 , there are $1,966,514,816$ Internet users worldwide, penetrating $28.7 \%$ of the population $(6,845,609,960)$. The growth rate between 2000 and 2010 is $444.8 \%$. In 2014, the Internet will be four times larger than it was in 2009" (Colado, September 2010).

Consumers are becoming increasingly comfortable with technology. As the marketplace for technology based products continues to grow, more than "tech savvy" consumers are considered target markets. Many people not only have mobile phones, but also have Internet access through their handheld devices. Consumers' expectations of technology providers have increased as well.

\section{THE CHANGING RELATIONSHIP OF SERVICE PROVIDERS AND CONSUMERS}

According to the International Telecommunicating Union's (ITU) "The World in 2010" report, there was an estimated 5.3 billion mobile cellular subscriptions worldwide at the end of 2010 (Shein, 2010). And, $90 \%$ of the world's population has access to mobile networks (Shein). As the cellular market in developed areas reaches near saturation levels, consumer demands will shift from simply wanting coverage and devices, to wanting worldwide converged mobile devices (Smartphones) and new, enticing applications.

Consumers have been gaining power in their relationship with cell phone carriers. This shift comes in part due to increasing familiarity with the industry, and because consumers simply enjoy more choices. Carriers have 
more competition among themselves, while they are also faced with shorter product life cycles and increasing costs of research and development.

Carriers want to offer the technology that meets consumer demands, and preferably have it quicker and with less investment. Apps offer a way for companies to be competitive and meet consumer needs. The Pew Internet Project conducted a study to determine how quickly consumers are embracing the use of applications on their mobile devices. "Of the $82 \%$ of U.S. adults who are now active cell phone users, $43 \%$ now have apps on their phones, and more than two-thirds of them use those apps regularly. In other words, $24 \%$ of the U.S. adult population actively uses apps, the study estimates" (Indvik, 2010). This is perhaps even more surprising considering that until several years ago, applications were not even available.

"Of the $82 \%$ of Americans using mobile devices, nearly one-third of them have downloaded apps, and $13 \%$ said they have paid for one or more of those apps. More than half of those who said they had downloaded an app claimed they had done so within the last 30 days, and one-third had in the last week" (Indvik). Consumers who shop for apps seem to do it regularly. This provides significant opportunities for developers, as they can continually be creating apps to meet consumer needs and tap into trends. Of those consumers who downloaded apps in the last month, $60 \%$ have downloaded games, $52 \%$ downloaded news/weather, 51\% downloaded maps/navigation, and $47 \%$ social networking. Other categories frequented included, entertainment/food, sports and shopping/retail (Indvik).

Internet shopping has become increasingly popular. Many consumers have Internet capabilities on their mobile phones, and are using their phones for shopping. Mobile shopping peaked during 2010; eBay led the way by becoming the go-to-shopping destination for mobile shopping (BusinessWire, December 2010). "With more than 30 million downloads of eBay's mobile apps worldwide, eBay is clearly a barometer for mobile shopping trends. We see people buying everything from designer apparel to cars and trucks on their phones regularly, and purchases being made through eBay mobile every second" (BusinessWire, December 2010).

The use of apps to shop presents opportunities for both consumers and developers. Consumers have more information readily available to them. Apps engage them in the purchasing process at times when they normally would not be shopping. Apps can be part of the search and purchase process or may be used to facilitate the entire process. Developers have an opportunity to create an increasing array of potential apps - the breadth of app categories can increase just as can the depth of the categories. Developers can view consumer feedback regarding their apps and either publish updates or design new products. Companies can make sure apps are available that create differential benefits for the consumers, and, ultimately, themselves.

As the use of apps increases, the target market for apps also grows. At year end 2010, mobile app users tended to be younger, male, and more affluent relative to the general population (Indvik). This is not unlike the characteristics of many technology products' target markets in the early stages of introduction and adoption. As consumers become more knowledgeable and comfortable with technology, the demographics and psychographics of these users are expected to change. Simply stated, app users will increasingly be from the general population, as well as the tech-savvy consumers. Just as many consumers adjusted to having mobile phones, they will begin utilizing their phones for informational purposes as well. It is conceivable that consumers will begin to fully utilize and somewhat depend on their mobile phone's apps, just as many now use texting and Internet access on their phones.

\section{DEVELOPING AN APPLICATION}

The process of developing applications is changing, and indicates a shift of power. In the past, software companies and mobile carriers invested time and money in the development of new products. When app development first began, individual developers had little opportunity to move their products to market. It often took six to nine months just for the developers to get a meeting with carriers. "Developers had to pitch their app, it had to be accepted, often modified and ported across all handsets, and a business model had to be worked out. In traditional carrier environments, there were no options for pricing outside of a few pre-determined price points. And there was no choice of handsets. It had to span their entire portfolio" (Reedy, 2009). 
The development of applications is now different. Anyone can develop an application and place it in an app marketplace. The app stores can then sell the applications to consumers or they can make the applications free and sell advertising that will appear in the apps. In 2010, "Angry Birds" became one of the most popular free apps. Users see a variety of advertisements pop up as they play the game, though they never have to pay to play.

Developers have many options when seeking to move their apps to market. There are two dominant operating systems in the app market place - the Google Android system and the Apple system. Google's Android application market reached about 200,000 available apps by the end of 2010. This benchmark is nearly twice the available apps available just months ago (Rey, 2010). Despite this achievement by Google, the Apple App Store still wins with over 300,000 apps available for download (Rey). Apple could exceed the 500,000 app mark by June of 2011, if every app is approved (Electronista). Apple sees over 25,400 apps submitted per month (Electronista). There are other portals for apps, though they are trailing Android and Apple. BlackBerry App World reached 15,000 titles fall of 2010. Palm App Catalog and Windows Phone Marketplace reached 5,000 by the end of 2010 (Electronista).

Apple apps can only be used on Apple products (iPhones and iPads), while Android apps can operate on a number of manufacturers' systems. Many view Apple as a "closed" system, while Androids are considered "open" because of this ability to be utilized by multiple manufacturers of Smartphones and tablets, and by multiple carriers.

Apple more tightly controls their apps in a way that the Android marketplace does not. Apps submitted to Apple go through an acceptance process before they are made available to consumers. Though this usually takes only a week or two, it is more time than with the Android system. Android apps can be posted immediately. Google can exert control and remove the app if wanted. Generally, removal of apps is done if the developer did not comply with the terms of service. Apple's control is designed to ensure the development of high quality apps (representative of Apple) and manage the user experience (Rey, 2010). But, Android can hurt Apple, and Apple's efforts to save their market share have led to many legal battles.

Table 1. Android vs. Apple: A Comparison For Developers

\begin{tabular}{|l|l|l|}
\hline & \multicolumn{1}{|c|}{ Apple } & \multicolumn{1}{|c|}{ Android } \\
\hline Time For Approval & Week or so & None \\
\hline Approval Necessary & $\begin{array}{l}\text { Approval required - subject to rejection. } \\
\text { Some express concern over lack of } \\
\text { information for rejection }\end{array}$ & None \\
\hline Merchant Account & Relatively Easy & Need U.S Address and Bank \\
\hline Countries - Worldwide & Excellent - 90 countries & Weak - 32 \\
\hline Number of Applications & $\begin{array}{l}\text { Over 300,000 (500,00 } \\
\text { possible by 6/2011) }\end{array}$ & 200,000 \\
\hline Ease of Payment for customer & Easy & $\begin{array}{l}\text { Burdensome- Google checkout. Trying } \\
\text { to improve }\end{array}$ \\
\hline Development Language & $\begin{array}{l}\text { Objective-C - Primarily an Apple } \\
\text { language }\end{array}$ & Java \\
\hline Development platform & Need Mac running Leopard Mac OS X & PC \\
\hline Development Tools available & Not as good & Excellent \\
\hline $\begin{array}{l}\text { Form Factors Developers must consider } \\
\text { Just iPhone }\end{array}$ & $\begin{array}{l}\text { Multiple form factors because Android is } \\
\text { offered on many different phones }\end{array}$ \\
\hline Payment & Minimum payout of \$250 or no payout & Minimum payout \$1 \\
\hline $\begin{array}{l}\text { Sources: (1) Android versus the iPhone Development: A Comparison; (2) Hill (2010). Android Market vs. Apple App Store; (3) } \\
\text { Bauer (2010); Developers Loving Android More and More; (4) Wortham (2010). App Makers Take Interest in Android; (5) Paul } \\
\text { (2011) Google hopes to fix weak growth of Android Market app purchases. }\end{array}$
\end{tabular}

Developers experience other considerations when deciding on an operating system (see Table 1). Initial investment is an issue. Apple has many requirements necessary to develop for them; Android does not. If a developer does not already have the equipment, it may not be worthwhile to develop for Apple. Anyone with a PC can develop for Android. Android has a slight advantage in that it provides development tools and can be used by many forms. 
Apple's marketplace is a bit more user-friendly regarding consumer payment than Android's. Google is working to remedy this; however, this could be an area of consideration to developers since they are sometimes compensated through downloads. Developers are compensated for their products through either Google or Apple. They sign an agreement with the companies regarding the structure of compensation. If the app is free to consumers, revenue is generated through advertising. If the app is not free, a different agreement is signed where the proceeds are split according to a pre-determined amount. Google pays their app developers after they generate revenues. Apple waits until the app has generated enough money that the developers' share is $\$ 250$, to pay the developer.

The growth of the computer tablet market is expected to influence the availability of apps. Apple was somewhat ahead of the competition with the iPad, which made for an increase in app usage as well. As more tablets become available that utilize the Android system, the need for Android apps will increase (Electronista). It is expected that tablets will be gaining in popularity, and many manufacturers will be making them available. Thus, while Apple captured an early market share lead in the tablet category, the company will face increasing competition in the coming years.

\section{TEACHING THE CASE}

This case is designed to look at the methods of taking cell phone applications to market, which presents increasing opportunities for small developers. Most Americans own a cell phone, which makes the market somewhat saturated. Because of this, further development of options for phones is an area that companies can use to increase revenues and product offerings to their customers. Applications are becoming used more widely by more types of consumers.

The development process of products has changed. Small developers can move their applications to market, instead of the industry be dominated by large corporations as in the past. It also looks at how consumer demand and trends control what is available in the marketplace. Many students will be familiar with apps, perhaps very familiar. Most Smartphones come equipped with apps, so it is not new to many students.

It would be interesting to lead classroom discussions regarding:

1. How and why they would choose which operating system (Apple or Android) to take their apps to market if they were developers?

2. What issues need to be considered in the development process?

3. What is their preference as a consumer-Apple or Android — and why?

4. Students' opinions of and use of apps. (What makes them interested in certain apps? How many apps do they download regularly? Are they willing to buy apps, and, if so, why? )

5. Where do the students see the direction of the app market going?

6. What ideas do students have for apps?

The following are questions and answers that students could respond to individually or working in small groups:

\section{QUESTIONS/ANSWERS}

Question 1\#: How does one go about taking an app idea to market (turning an idea into a product)?

Answer: Student answer will vary, though they should mention that developers must first decide which operating system they are going to make their app available through. If the developer uses the Android operating system, their app can be used with variety of manufacturers' products. If the developer chooses to sell to Apple, then the product can only be used on Apple products. Developers sign an agreement with an operating system and then the app becomes available as agreed upon. 
Question \#2: What are different considerations regarding control if a developer goes through the Google Android system or tries to sell their product to Apple?

Answer: Answers should contain information found in Table 1, as they are development considerations. Initial investment, time for approval, and development tools available should be discussed. The developer will have less control when they sell their product through Apple, and possibly face greater delays in getting their product out. Their product may have a sense of quality among some consumers since it is an Apple product. Android gives the developer more control, even though Google can pull the app if necessary. Android could provide more creative freedom for the developer, and possibly be quicker to get to market. Trends could be tapped into more easily, especially trends that may not fit with Apple and their corporate identity.

Question \#3: What are considerations for consumers regarding use of the Android operating system versus the Apple?

Answer: Students are probably familiar with the Android vs. Apple battle, and many will have personal preferences. Many consumers do not want to be part of a "closed" system, while others believe the Apple system has benefits that outweigh the negative aspects of the system. It is a matter of personal preference. Students should expand on the different systems and the advantages and disadvantages of both.

Question \#4: In your opinion, what will motivate consumers to find and download applications? How can developers make their apps appealing to consumers in the future?

Answer: Students answers will vary. They should either discuss price, availability, product features, or product offerings. The apps will have to possess qualities that attract consumers. They need to be timely and show some differential benefit compared to other apps. Developers need to be in touch with trends and the competition.

\section{CONCLUSION}

Customer expectations will continue to grow and affect the app market place. Trends can be started, or strengthened through an app, even the lifespan of a product extended. It can be another method to show consumers the value and potential benefits of products and the benefits of the app itself. Consumers will continue to want more apps that make their lives easier. From personal to business purposes, the use and growth of apps appears endless. Companies are facing how to develop meaningful apps that can pay for themselves, and set them apart from the competition.

\section{AUTHOR BIOGRAPHY}

Kristen Maceli is an Assistant Professor in the Management and Marketing Department at Pittsburg State University (PSU) in Pittsburg, Kansas. She began teaching at PSU in 2001, and has been on faculty since 2008. She holds a B.S. degree from Kansas University, an M.B.A. from Pittsburg State University, and a Ph.D. from Kansas University. Dr. Maceli's primary areas of research are marketing, education, and the changing workforce.

\section{REFERENCES}

1. Android versus iPhone Development: A Comparison (July 2, 2009). Retrieved January 28, 2011 from http://greensopinion.blogspot.com/2009/07/android-versus-iphone-development.html

2. Alpern, Peter (December 2010). Bringing Digital Sense to a Global Enterprise. Industry Week, Vol. 259, Iss. 12, p. 44.

3. Anonymous. BusinessWire. "From the Winter Olympics to Designer Handbags and Sports Cars, MCommerce Leader eBay® ${ }^{\circledR}$ Shares Global Mobile Shopping Moments for 2010,” New York: December 29, 2010.

4. Anonymous. Business Wire. "Worldwide Converged Mobile Device (Smartphone) Market Grows 56.7\% Year Over Year in First Quarter of 2010, Says IDC," New York: May 7, 2010. 
5. Anonymous. PR Newswire. "Hispanics are Important Mobile Marketing Targets; More than Eight in Ten Hispanic Adults Use a Cell Phone; Hispanics More Likely than other Cellular Users to Text Message; Hispanic Smartphone Growth Rate Outpaces that of Total Population,” New York: December 20, 2010.

6. Apple's App Store Likely to Crack 500,000 apps in 2011 (December 30, 2010). Retrieved from http://www.electronista.com/articles/10/12/30/app.store.could.pass.500000.active.titles.in .2011/

7. Bauer, Jesse (October 25, 2010). Developers Loving Android More and More. Retrieved January 27, 2011, from http://www.talkandroid.com/192222-developers-loving-android-more-and-more/

8. Bradshaw, Tim and David Gelles (2010, May 14). Adobe hits back at Apple over. Flash. Financial Times, 14. Retrieved January 25, 2011, from ABI/INFORM Global. (Document ID: 2033489731).

9. Chiang, Oliver (2011). Unhappy with Slow Growth of Android App Purchases, Google Talks 2011 Roadmap. Forbes. January 25, 2011.

10. Colado, Liz (September 2010). (9/2010) Mind Control: The Future of Brain Implants. McClathchy-Tribune Business News. Washington: September 28, 2010.comScore Reports November 2010 U.S. Mobile Subscriber Market Share (January 6, 2011). Retrieved from http://www.comscore.com/Press_Events/Press_Releases/2011/1/ comScore Reports_November_2010_U.S. Mobile_Subscriber_Market Share

11. Fleming, Jeffrey \& Brandon Sheffield (October, 2010). Companies to Watch. Game Developer, $17(9), 7$. Retrieved January 25, 2011, from ABI/INFORM Trade \& Industry. (Document ID: 2153016651).

12. Indvik, Lauren (September 14, 2010). 1 in 4 Adults Now Use Mobile Apps. Retrieved from http://mashable.com/2010/09/14/mobile-apps-pew-survey/

13. Hill, Simon (February 12, 2010). Android Market vs. Apple App Store. Retrieved January 28, 2011 from http://www.brighthub.com/mobile/google-android/articles/63772.aspx

14. Ionescu, Daniel (November 19, 2010). Angry Birds Devs Angry At Android Fragmentation. PC World.

15. Menn, Joseph (October 19, 2010). Apple iPad sales fail to hit forecasts. Financial Times, 1. Retrieved January 25, 2011, from ABI/INFORM Global. (Document ID: 2167011621).

16. Mobile Phone Market Growth Slows, but don't panic (July 2010). Retrieved from http://www.electronicsweekly.com/Articles/2010/07/30/49178/mobile-phone-market-growth-slows-butdont-panic.htm

17. Pankratiu, Victor, Wolfram Schulte, Kurt Keutzer (January/February 2011). Paralellism on the Desktop. IEEE Software, p. 14-16.

18. Paul, Ryan (2011). Google hopes to fix weak growth of Android Market app purchases. Retrieved from http://arstechnica.com/gadgets/news/2011/01/why-google-is-seeing-weak-growth-of-android-apppurchases.ars

19. Reedy, Sarah. "Breaking Down The Walled Garden" Connected Planet 1 Dec. 2009.

20. Rothaermel, F., and A. Hess. "Innovation Strategies Combined." MIT Sloan Management Review 51.3 (2010): 13. ABI/INFORM Global, ProQuest. Web. 25 Jan. 2011.

21. Rey, Francis (December 28, 2010). Google Android Market Reaches 200,000 Apps. Retrieved from http://socialbarrel.com/google-android-market-reaches-200000-apps/2109/

22. Robat, Cornelis. Introduction to Software History. Retrieved from http://theocp.net/software/software reference/introduction to software history.htm

23. Shein, Esther (October 19, 2010). Mobile Networks Penetrate 90\% Of World's Population. Retreived from http://www.informationweek.com/news/smb/mobile/showArticle.jhtml?articleID=227900281\&cid=RSSfee d IWK ALL

24. Wortham, Jenna (2010). App Makers Take Interest in Android. The New York Times, October 24, 2010. 